\title{
Diversity patterns and freshwater molluscs similarities in small water reservoirs
}

\author{
TOMÁŠ ČEJKA \\ Slovak Academy of Sciences, Institute of Zoology, Dúbravská cesta 9, SK-84104 Bratislava, Slovak Republic, \\ e-mail: tomas.cejka@savba.sk
}

ČEJKA T., 2011: Diversity patterns and freshwater molluscs similarities in small water reservoirs. - Malacologica Bohemoslovaca, 10: 5-9. Online serial at $<$ http://mollusca.sav.sk $>22-F e b-2011$.

\begin{abstract}
The survey presents the molluscan fauna from six impoundment systems of two sides (NW and SE) of the Small Carpathians. Altogether 25 species (15 gastropod and 10 bivalve) species were identified in reservoirs and their subsystems (inflows and outlets). The number of species per site ranged from 2 to 12 , the mean number of species per site was 7. The mean number of individuals per site ranged from 15 to 905 (mean 174) ind $/ \mathrm{m}^{2}$. Radix auricularia, R. ovata, Gyraulus albus, Gyraulus parvus/laevis, Hippeutis complanatus and Pisidium casertanum were present in more than $50 \%$ of reservoirs. The most abundant and frequent species in the entire area and all subsystems were Pisidium casertanum, Pisidium subtruncatum and Gyraulus parvus/laevis. Faunistic similarity indices indicate moderate degree of beta diversity i.e., differentiation among the sites; good separation of sites by cluster analysis indicates a different composition among inflows/outlets and littoral molluscan faunas of reservoirs.
\end{abstract}

Key words: Small Carpathians, Slovakia, stream impoundments

\section{Introduction}

Impoundments are features that significantly slow the rates of transport of water; elevate water loss to evaporation; alter rates, pathways and locations of chemical reactions in freshwater and disrupt freshwater aquatic habitats by fragmenting water flow to the lower part of the watershed (Sмith et al. 2002). A dam is a structure that blocks or impounds water for the purpose of retaining the water or preventing or diverting the flow of water. Historically reservoirs were first constructed for irrigation. In more recent years, the first reservoirs were built for flood protection; other uses followed, including augmentation of river flow for irrigation of crops below reservoir; navigation; drinking and industrial water supply; fisheries, and; more recently, power generation and recreation. Storage of a certain quantity of water is usually the primary interest of the reservoir manager. The damming system consists of three main subsystems - inflow, reservoir and outlet. The scarce literature from the area of Small Carpathians area revealed the coincidence of natural lowland biotopes with some rare and endangered species. Mainly the Rudava brook with its typical sandy bottom and the Stupavský Potok brook with its mountain character supporting a number of mountain and submountain species belong to well preserved natural biotopes of this region (KRNO \& al. 1994). Other studies were focused on streams in the Small Carpathians, mainly in the Vydrica stream basin (KRnO 1984, 1986, KRno \& Hulloví 1998) and in the Gidra stream basin (DERKA 2003, KRNO 2003, RodRIGUEZ \& Derka 2003, LuKÁš \& KRno 2003). Molluscan surveys absent from the small water reservoir systems in the area around and in the Small Carpathians. Primarily I aimed to: (i) describe species richness and composition, (ii) assess degree of similarity of molluscan faunas in impoundment subsystems (iii) identify, if there are some characteristic species in single subsystems.

\section{Study sites}

The study was located around the Small Carpathian Mts., SW Slovakia $\left(48^{\circ} 24^{\prime} \mathrm{N}, 17^{\circ} 15^{\prime} \mathrm{E}\right)$. Six impoundment subsystems (inflows, littoral of the reservoirs and their outlets, see Figs 1-6) belong to two watershed were chosen (Váh and Morava Rivers, see below). Three of them are situated on the NW slopes of the Small Carpathians (Morava River watershed) and three were located at the Trnavská Pahorkatina uplands below SE slopes of the Small Carpathians (Váh River watershed). The main features of the impoundments are shown in Table 1. The reservoirs belonging to the Váh River watershed were Dol'any, Suchá nad Parnou, and Dolné Dubové. The reservoirs are situated in the agricultural landscape up to $200 \mathrm{~m}$ a.s.1. The inflows in SE slopes are suffered from fertiliser and the runoff of surrounding settlements, inflows in NW slopes are relatively unpolluted. The reservoirs are used for water supply and fish stocking; reservoirs belonging to the Morava River watershed were Kuchyn̆a, Lozorno, and Vývrat are situated on the west side of the Small Carpathiabns up to 260 $\mathrm{m}$ a.s.l. The inflows flow through the protected landscape area "Small Carpathians"; the reservoirs Kuchyňa and Lozorno are part of the Ramsar Convention on wetlands (KLEMENTOVÁ \& JuRÁKOVÁ 2003). The outlets of all six reservoirs are altered by channel regulation and high water fluctuation depending on discharge manipulation, together with organic pollution from agriculture and urban waste. 


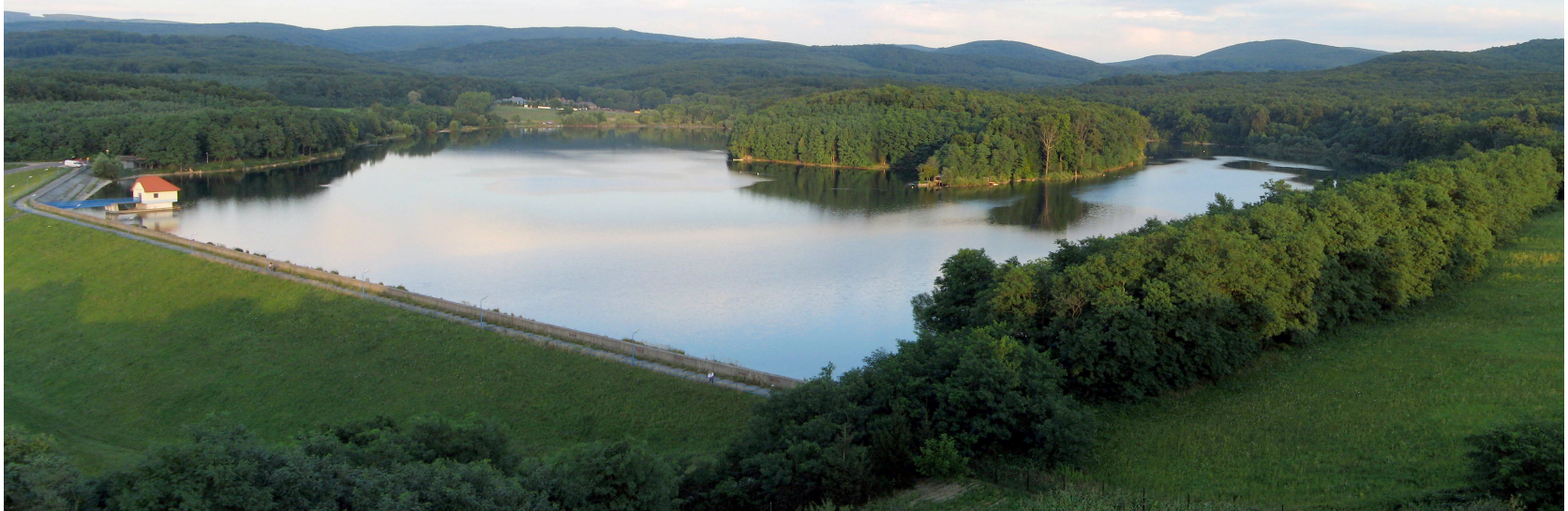

Fig. 1. Aerial view of the Lozorno reservoir (Photo P. Bálik).

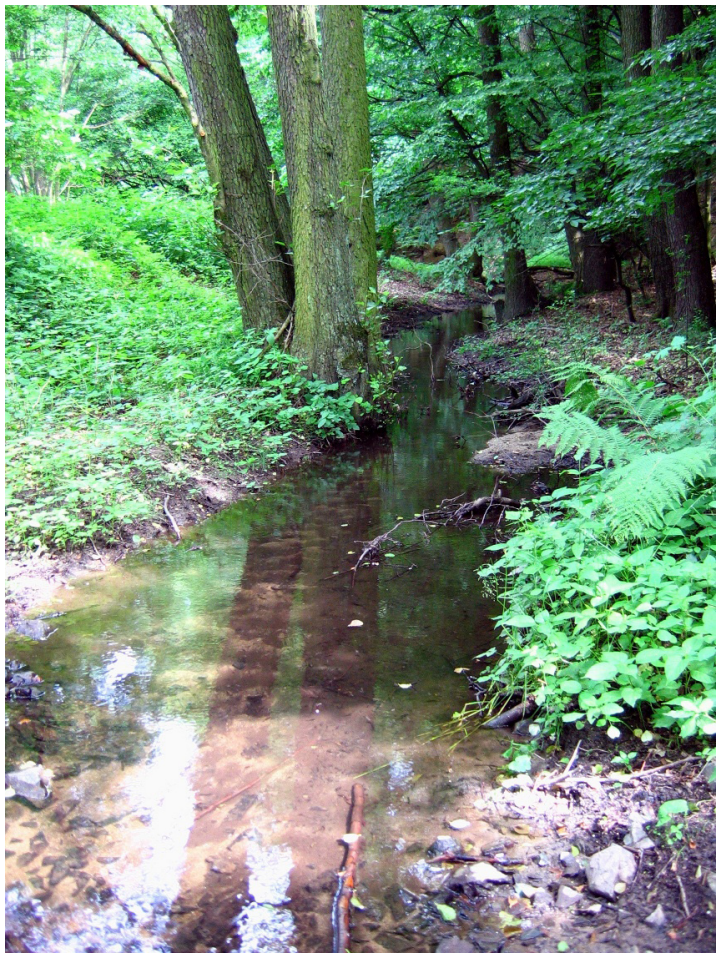

Fig. 2. Natural character of the inflow of the Lozorno reservoir (Photo T. Čejka).

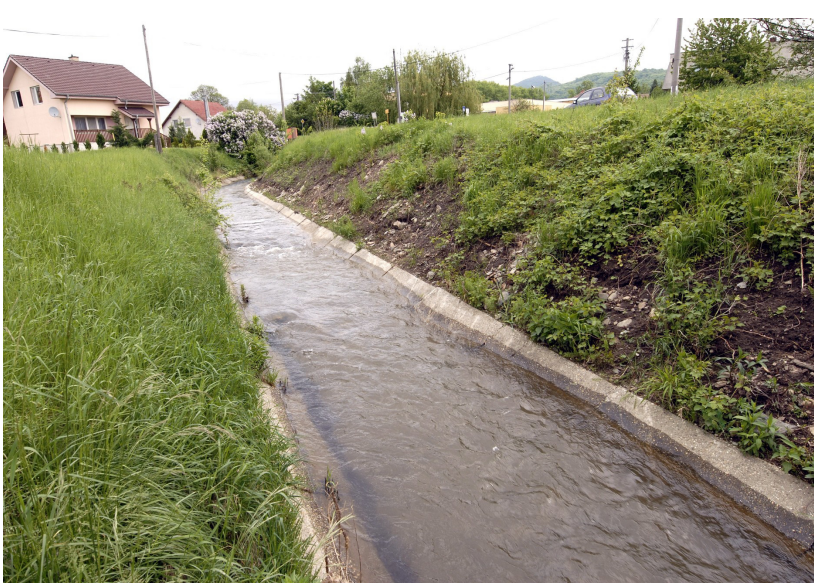

Fig. 3. Channelised outlet of the Kuchyňa reservoir (Photo F. Čiampor).

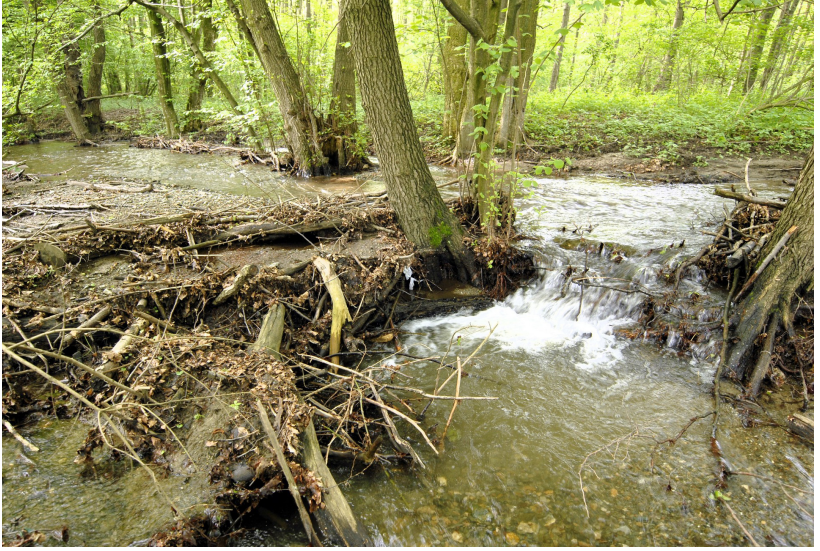

Fig. 4. Inflow of the Kuchyňa reservoir. Natural bed character with a huge amount of coarse woody debris (Photo F. Čiampor).

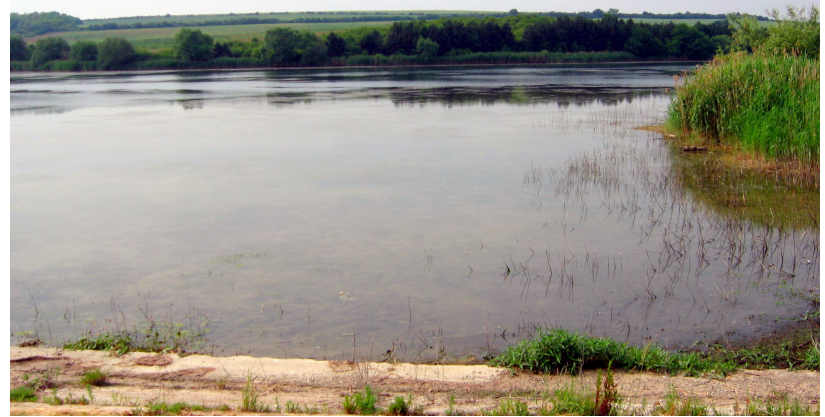

Fig. 5. Semi natural character of the littoral at the Dol'any reservoir (Photo T. Čejka).

\section{Material and methods}

\section{Mollusca sampling}

Sampling was conducted at six impoundments (inflows, littorals, outlets; a total of 18 sites) each second month from September 2008 to May 2010. In total 144 samples within 1.5 year were taken. Three to five replicate macroinvertebrate samples were taken at each site and depth. Two types of sampling devices were used to collect benthic macroinvertebrates: for quantitative sampling in 


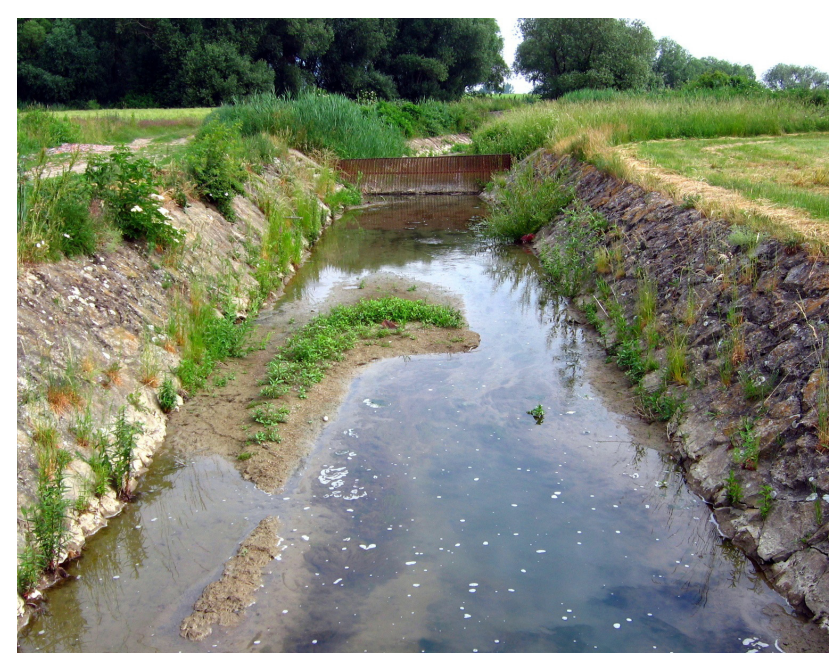

Fig. 6. Channelised outlet of the Dol'any reservoir (Photo T. Čejka).

shallow regions Surber sampler $\left(0.10 \mathrm{~m}^{2}\right.$, mesh $\left.0.4 \mathrm{~mm}\right)$, for qualitative sampling the D-shape kick-net were used. All debris and rocks collected in the area enclosed by the Surber sampler were brushed clean and dislodged material was collected on a $0.5 \mathrm{~mm}$ mesh sieve. All samples were preserved in $96 \%$ etanol in the field. Samples containing large volumes of sand were sorted in the field by repeated washing of sediments and passing the water through a 0.5 $\mathrm{mm}$ sieve to collect molluscs. On return to the laboratory, molluscs were separated from macrophytes and detritus using an inclined, running water drained through a $0.5 \mathrm{~mm}$ mesh sieve. Number of species per site, total abundance, and abundances of individual species per $\mathrm{m}^{2}$ were calculated. Mollusca were identified from keys in GLÖER \& MEIER-BROOK (2003) and Horsák (2003). The nomenclature follows Horsák et al. (2010).

\section{Analyses}

The species abundance data were log-transformed as $Y=$ $\log _{10}(n+1)$ in order to reduce the influence of predominant species. Beta-diversity was assessed with Whittaker's in-
$\operatorname{dex}\left(I_{w}=\right.$ total no. of species divided by the mean number of species; WhITTAKer 1972), and its variant $\left(\mathrm{I}_{\max }=\right.$ total no. of species divided by the number of species in the richest site recorded), as indicators of faunal differentiation between sites in the same region (CAMERON \& PokryszKo, 2005). The latter index eliminates the effect of site faunas that are merely impoverished versions of others, rather than containing distinctive species not found elsewhere. The species-by-sites matrix was classified by cluster analysis to evaluate the similarity of individual communities. Dissimilarities was calculated using Ward method (Bray-Curtis dissimilarities), performed by ' $\mathrm{R}$ ' software, package 'vegan' (OKSANEN et al. 2010). Frequency and dominance were calculated for each species, as well as "importance" index (frequency $\times$ dominance) which reflects the significance of the species in the whole set of sites (PotoczaK \& PoKryszKo 2008).

\section{Results}

Species list, density, constancy

The list of species is presented in Table 2. Twenty five molluscan species were recorded from the surveyed reservoirs and their subsystems (15 gastropod and 10 bivalve species). The number of species per site ranged from 2 to 12 , the mean number of species per site was 7 . The mean number of individuals per site ranged from 15 (site 10) to 905 (site 14) (mean 174) ind. $/ \mathrm{m}^{2}$. In more than $50 \%$ of reservoirs were present Radix auricularia, R. ovata, Gyraulus albus, Gyraulus parvus/laevis, Hippeutis complanatus, and Pisidium casertanum.

\section{Composition of molluscan communities, beta diversity}

The most abundant and frequent species in the entire area and all subsystems were Pisidium casertanum, Pisidium subtruncatum, and Gyraulus parvus/laevis. Inflows were characterised by Pisidium casertanum, P. subtruncatum, and Ancylus fluviatilis; littorals were characterised by Gyralus parvus/laevis, G. albus, Radix auricularia, and

Table 1. The list of sites under study.

\begin{tabular}{|c|c|c|c|c|c|c|c|}
\hline Municipality & Site code & Subsystem & Coordinates (N,E) & Region & Mean altitude & Area (ha) & Spp. No. \\
\hline Dol'any & InDo & inflow & $48^{\circ} 24^{\prime} 01^{\prime \prime}, 17^{\circ} 23^{\prime} 32^{\prime \prime}$ & SE & 195 & - & 10 \\
\hline Dol'any & LiDo & littoral & $48^{\circ} 24^{\prime} 11^{\prime \prime}, 17^{\circ} 24^{\prime} 50^{\prime \prime}$ & SE & 195 & 16 & 6 \\
\hline Dol'any & OuDo & outlet & $48^{\circ} 24^{\prime} 18^{\prime \prime}, 17^{\circ} 25^{\prime} 16^{\prime \prime}$ & SE & 195 & - & 9 \\
\hline Suchá n.P. & $\mathrm{InSu}$ & inflow & $48^{\circ} 24^{\prime} 42^{\prime \prime}, 17^{\circ} 26^{\prime} 02^{\prime \prime}$ & SE & 197 & - & 8 \\
\hline Suchá n.P. & $\mathrm{LiSu}$ & littoral & $48^{\circ} 24^{\prime} 47^{\prime \prime}, 17^{\circ} 28^{\prime} 19^{\prime \prime}$ & SE & 197 & 31 & 6 \\
\hline Suchá n.P. & $\mathrm{OuSu}$ & outlet & $48^{\circ} 24^{\prime} 33^{\prime \prime}, 17^{\circ} 29^{\prime} 15^{\prime \prime}$ & SE & 197 & - & 8 \\
\hline Dolné Dubové & InDD & inflow & $48^{\circ} 30^{\prime} 54^{\prime \prime}, 17^{\circ} 34^{\prime} 00^{\prime \prime}$ & SE & 191 & - & 4 \\
\hline Dolné Dubové & LiDD & littoral & $48^{\circ} 30^{\prime} 09^{\prime \prime}, 17^{\circ} 35^{\prime} 37^{\prime \prime}$ & SE & 191 & 12 & 5 \\
\hline Dolné Dubové & OuDD & outlet & $48^{\circ} 30^{\prime} 00^{\prime \prime}, 17^{\circ} 35^{\prime} 49^{\prime \prime}$ & SE & 191 & - & 7 \\
\hline Kuchyňa & $\mathrm{InKu}$ & inflow & $48^{\circ} 23^{\prime} 59^{\prime \prime}, 17^{\circ} 10^{\prime} 04^{\prime \prime}$ & NW & 260 & - & 2 \\
\hline Kuchyňa & $\mathrm{LiKu}$ & littoral & $48^{\circ} 24^{\prime} 09^{\prime \prime}, 17^{\circ} 10^{\prime} 02^{\prime \prime}$ & NW & 260 & 12 & 12 \\
\hline Kuchyňa & $\mathrm{OuKu}$ & outlet & $48^{\circ} 24^{\prime} 12^{\prime \prime}, 17^{\circ} 09^{\prime} 17^{\prime \prime}$ & NW & 260 & - & 6 \\
\hline Lozorno & InLo & inflow & $48^{\circ} 19^{\prime} 24^{\prime \prime}, 17^{\circ} 04^{\prime} 44^{\prime \prime}$ & NW & 219 & - & 7 \\
\hline Lozorno & LiLo & littoral & $48^{\circ} 19^{\prime} 27^{\prime \prime}, 17^{\circ} 04^{\prime} 09^{\prime \prime}$ & NW & 219 & 35 & 12 \\
\hline Lozorno & OuLo & outlet & $48^{\circ} 19^{\prime} 44^{\prime \prime}, 17^{\circ} 03^{\prime} 23^{\prime \prime}$ & NW & 219 & - & 5 \\
\hline Rohožník & InRo & inflow & $48^{\circ} 25^{\prime} 49^{\prime \prime}, 17^{\circ} 10^{\prime} 12^{\prime \prime}$ & NW & 237 & - & 7 \\
\hline Rohožník & LiRo & littoral & $48^{\circ} 26^{\prime} 00^{\prime \prime}, 17^{\circ} 10^{\prime} 11^{\prime \prime}$ & NW & 237 & 10 & 6 \\
\hline Rohožník & OuRo & outlet & $48^{\circ} 26^{\prime} 05^{\prime \prime}, 17^{\circ} 09^{\prime} 54^{\prime \prime}$ & NW & 237 & - & 11 \\
\hline
\end{tabular}


Table 2. List of species in individual reservoir subsystems. In - inflow; Li - reservoir littoral; Ou - reservoir outlet; settlements: Do - Dol'any; Su - Suchá n. Parnou; DD - Dolné Dubové; Ku - Kuchyňa; Lo - Lozorno; Ro - Rohožník; NS - number of sites with species presence; C (\%) - constancy [proportion of sites with species presence (in \%)].

\begin{tabular}{|c|c|c|c|c|c|c|c|c|c|c|c|c|c|c|c|c|c|c|c|c|}
\hline & \begin{tabular}{|l|} 
In \\
Do \\
\end{tabular} & \begin{tabular}{l|}
$\mathbf{L i}$ \\
$\mathbf{D o}$ \\
\end{tabular} & \begin{tabular}{|l|} 
Ou \\
Do
\end{tabular} & \begin{tabular}{l|} 
In \\
Su
\end{tabular} & \begin{tabular}{|l|}
$\mathbf{L i}$ \\
$\mathbf{S u}$
\end{tabular} & \begin{tabular}{|l|} 
Ou \\
Su
\end{tabular} & $\begin{array}{l}\text { In } \\
\text { DD }\end{array}$ & \begin{tabular}{|c|}
$\mathbf{L i}$ \\
$\mathbf{D D}$
\end{tabular} & $\begin{array}{l}\text { Ou } \\
\text { DD }\end{array}$ & $\begin{array}{l}\mathbf{I n} \\
\mathbf{K u} \\
\end{array}$ & $\begin{array}{c}\mathbf{L i} \\
\mathbf{K u} \\
\end{array}$ & $\begin{array}{l}\mathbf{O u} \\
\mathbf{K u}\end{array}$ & \begin{tabular}{|l|} 
In \\
Lo \\
\end{tabular} & \begin{tabular}{|l|}
$\mathbf{L i}$ \\
$\mathbf{L o}$ \\
\end{tabular} & $\begin{array}{l}\text { Ou } \\
\text { Lo }\end{array}$ & \begin{tabular}{|l|} 
In \\
Ro \\
\end{tabular} & \begin{tabular}{|l|}
$\mathbf{L i}$ \\
$\mathbf{R o}$ \\
\end{tabular} & $\begin{array}{l}\text { Ou } \\
\text { Ro }\end{array}$ & NS & \begin{tabular}{|c|}
$\mathrm{C}$ \\
$(\%)$
\end{tabular} \\
\hline Bythinella austriaca sensu lato & 4 & & & 3 & & & & & & & & & & & & & & & 2 & 11 \\
\hline Galba truncatula (O. F. Müller, 1774) & 10 & & 9 & 5 & 3 & & & & 5 & & 4 & & 3 & & 6 & 3 & & 5 & 10 & 56 \\
\hline Lymnaea stagnalis (Linnaeus, 1758) & & & 2 & & & & & & & & & & & & & & & & 1 & 6 \\
\hline Radix auricularia (Linnaeus, 1758) & & 16 & & & & 3 & & 8 & 11 & & 5 & 3 & 3 & 5 & 5 & & 3 & 1 & 11 & 61 \\
\hline Radix ovata (Draparnaud, 1805) & & 3 & & & 15 & & 2 & 5 & 12 & & 2 & & & 10 & 3 & & & 5 & 9 & 50 \\
\hline Radix peregra (O. F. Müller, 1774) & 10 & & 3 & & & 3 & 3 & & 15 & & & 5 & & & & 6 & & 12 & 8 & 44 \\
\hline Aplexa hypnorum (Linnaeus, 1758) & & 1 & & & & & & & & & & & & & & & & & 1 & 6 \\
\hline Physella acuta (Draparnaud, 1805) & & & & & & & & & & & 2 & & & 20 & & & & & 2 & 11 \\
\hline Acroloxus lacustris (Linnaeus, 1758) & & & & & & & & & & & & & & & & & 5 & & 1 & 6 \\
\hline Ancylus fluviatilis O. F. Müller, 1774 & 61 & & & 13 & & & & & & & & 5 & & & 5 & 8 & & & 5 & 28 \\
\hline Anisus leucostoma (Millet, 1813) & & 3 & & & & & & & & & & & & 3 & & & & & 2 & 11 \\
\hline Gyraulus albus (O. F. Müller, 1774) & & 5 & 3 & 2 & 13 & & & 12 & & & & 2 & & 12 & & & 25 & 1 & 9 & 50 \\
\hline Gyraulus crista (Linnaeus, 1758) & & & & & & & & & & & & & & & & & 5 & 2 & 2 & 11 \\
\hline Gyraulus parvus/laevis* & 2 & 15 & 4 & 2 & 8 & 2 & & 3 & 10 & & 3 & & & 7 & & 3 & 60 & 2 & 13 & 72 \\
\hline Hippeutis complanatus (Linnaeus, 1758) & & & 3 & & 3 & & & & & & 2 & & & 15 & & & 5 & & 5 & 28 \\
\hline Anodonta anatina (Linnaeus, 1758) & & & & & & & & & & & 1 & & & 3 & & & & & 2 & 11 \\
\hline Musculium lacustre (O. F. Müller, 1774) & & & 22 & 7 & & 12 & & & 7 & & 2 & & & 4 & & & & 15 & 7 & 39 \\
\hline Pisidium casertanum (Poli, 1791) & 350 & & 18 & 44 & 7 & 50 & 77 & 3 & 260 & 12 & 8 & 13 & 98 & 3 & 4 & 82 & & 234 & 16 & 89 \\
\hline Pisidium milium Held, 1836 & 12 & & & & & 10 & & & & & & 3 & 5 & & & 4 & & 10 & 6 & 33 \\
\hline Pisidium nitidum Jenyns, 1832 & 3 & & & & & & & & & & & & & & & & & 5 & 2 & 11 \\
\hline Pisidium personatum Malm, 1855 & 24 & & & & & & & & & & & & 5 & & & & & & 2 & 11 \\
\hline Pisidium subtruncatum Malm, 1856 & 5 & & 52 & 22 & & 73 & 21 & & & 3 & 5 & & 5 & 3 & & 93 & & & 10 & 56 \\
\hline Pisidium tenuilineatum Stelfox, 1918 & & & & & & & & & & & & & 10 & & & & & & 1 & 6 \\
\hline Sphaerium corneum sensu lato & & & & & & 3 & & & & & & & & & & & & & 1 & 6 \\
\hline Dreissena polymorpha (Pallas, 1771) & & & & & & & & & & & & & & 820 & & & & & 1 & 6 \\
\hline Individuals & 481 & 43 & 116 & 98 & 49 & 156 & 103 & 31 & 320 & 15 & 34 & 31 & 129 & 905 & 23 & 199 & 103 & 292 & & \\
\hline Species & 10 & 6 & 9 & 8 & 6 & 8 & 4 & 5 & 7 & 2 & 10 & 6 & 7 & 12 & 5 & 7 & 6 & 11 & & \\
\hline
\end{tabular}

* The taxonomic status of Gyraulus parvus/laevis is not fully resolved yet; all individuals found in spring samples had no fully developed genitalia, so we have not been able to confirm their exact status.

R. ovata; in outlets were most abundant and frequent pill clams Pisidium casertanum, P. subtruncatum and snail Radix peregra. In the inflows and outlets the highest "importance" index have the species Pisidium casertanum and $P$. subtruncatum, in the reservoir littorals the species Gyraulus parvus/laevis, G. albus, Radix auricularia, and Pisidium casertanum.

Whittaker's index was $\mathrm{I}_{\mathrm{w}}=3.50$, maximum Whittaker's index $\mathrm{I}_{\max }=2.08$ indicates a moderate degree of beta diversity i.e., differentiation among the sites.

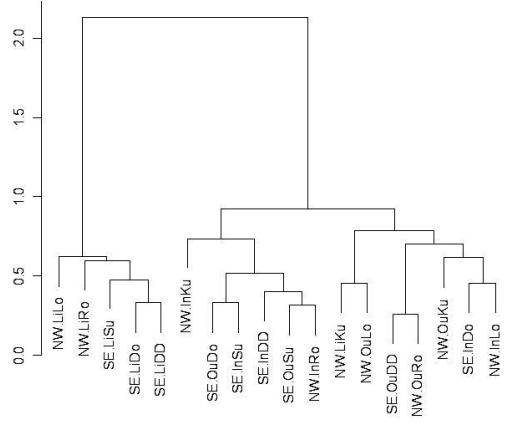

Fig. 7. Cluster analysis of molluscan communities based on their abundance $\left(\log _{10}(n+1)\right.$ transformation $)$, Bray-Curtis Index, Ward's method). For abbreviations see Table 1.

\section{Similarity of communities}

The primary division of the cluster analysis is for littorals and inflows/outlets, but within the (In+Out) cluster, the regional differences $(\mathrm{SE} / \mathrm{NW})$ are more prevalent than system type differences (In/Out). This indicates that littoral faunas are more homogeneous with respect to regions, while inflows and outlets are more similar to each others, but there a larger regional difference exists. Out of the "non littoral" (low abundance in littoral), only Musculium lacustre has greater abundance in outlets (Fig. 7).

\section{Disscusion}

\section{Speciess richness}

Water reservoirs (WR) we surveyed, had an area $<35$ ha. Strzelec \& Serafí́ski (2004) state from Poland in WR (n $=10)<100$ ha 23 species, while only 7 species occurred in more than $50 \%$ of the WR (see below). In the Czech Republic, BERAN (2002) distinguishes three types of WR: (i) oligotrophic reservoirs in higher altitudes (10 species, $\mathrm{n}$ =10), (ii) WR with a higher content of nutrients and rich of macrophytes (40 species, $\mathrm{n}=10$ ) and (iii) eutrophic WR with poor and species monotone presence of macro- 
phytes (18 species, $\mathrm{n}=10)$. Horsák et al. (2009) found 31 mollusc species (18 gastropods, 13 bivalves) in Nové Mlýny reservoirs in the South Moravia (Czech Republic). Comparing our results, they found species characteristic more likely for large lowland rivers (Lithoglyphus naticoides, Viviparus acerosus, Valvata piscinalis, probably more unionid species - they are not stated in the paper).

\section{Characteristic species}

Generally, BERAN (2002) states as characteristic "reservoir" species ( $>50 \%$ of WR) Lymnaea stagnalis, Gyraulus albus, Anisus vortex, Acroloxus lacustris, Radix auricularia, and Hippeutis complanatus. STRZELEC \& SERAFIŃSKI (2004) state as characteristic species Lymnaea stagnalis, Radix peregra, Stagnicola corvus, Planorbis planorbis, Gyraulus albus, Segmentina nitida, and Planorbarius corneus). In our study, the characteristic species were Radix auricularia, Radix ovata, Gyraulus albus, Gyraulus parvus/laevis, Hippeutis complanatus, and Pisidium casertanum. Generally, comparing these three sources the most characteristic species for small WR could be Lymnaea stagnalis, Radix auricularia Hippeutis complanatus, and Gyraulus albus.

\section{Red-listed and notable species}

There are four nationally red-listed species in surveyed area (ŠTEFFEK \& VAVRová 2006): pill clam Pisidium tenuilineatum (CR), Pisidium milium (VU), Pisidium nitidum (NT) and Aplexa hypnorum (NT).

\section{Acknowledgements}

I thank to Péter Sólymos (University of Alberta, Canada) and Michal Horsák (Masaryk University, Brno, Czech Republic) for useful comments regarding data presentation. The study was supported by the project SAV-FM-EHP-2008-03-04 and partly by VEGA No. 1/0362/09 and VEGA No. 2/0037/11. Thanks also go to all members of the project team.

\section{References}

Beran L., 2002: Vodní měkkýši České republiky - rozšíření a jeho změny, stanoviště, šíření, ohrožení a ochrana, červený seznam [Aquatic molluscs of the Czech Republic - distribution and its changes, habitats, dispersal, threat and protection, Red List]. - Sborník Př́rodovědného klubu v Uh. Hradišti, Supplementum 10, $258 \mathrm{pp}$.

Cameron R.A.D. \& Pokryszko B. M., 2005: Estimating the species richness and composition of land mollusc communities. - Journal of Conchology, 38: 529-547.

DerKa T., 2003: Ephemeroptera. - In: Slovak aquatic macroinvertebrates. Checklist and catalogue of autecological notes
ŠPORKA, F. (ed.) SHMÚ, Bratislava, pp. 290-314.

Glöer P. \& MeIER-Brook C., 2003: Süsswassermollusken. - Deutschen Jungendbund für Naturbeobachtung, Hamburg, $134 \mathrm{pp}$.

Honsák M., 2003: Mlži rodu Pisidium C. Pfeiffer (Mollusca: Bivalvia) České republiky [Bivalves of the genus Pisidium C. Pfeiffer (Mollusca: Bivalvia) of the Czech Republic]. - Acta Facultatis Ecologiae, Slovakia, 10, Suppl. 1: 219-229.

Horsák M., Bojková J., ZahrádKová S., Omesová M. \& Helešic J., 2009: Impact of reservoirs and channelization on lowland river macroinvertebrates: A case study from Central Europe. - Limnologica, 39: 140-151.

Horsák M., JuřičKová L., Beran L., ČejKa T. \& Dvořák L., 2010: Komentovaný seznam měkkýšů zjištěných ve volné př́irodě České a Slovenské republiky [Annotated list of mollusc species recorded outdoors in the Czech and Slovak Republics]. - Malacologica Bohemoslovaca (online), Suppl. 1: 1-37, http:// mollusca.sav.sk

Klementová E. \& JurákovÁ M., 2003: Wetlands in the Flood Control System. - Životní prostředí, 37: 200-203.

KRNO I. \& Hullová D., 1988: Influence of the water pollution on the structure and dynamics of benthos in the stream Vydrica (Small Carpathians). - Biologia, Bratislava, 43: 513-526.

KRNO I., 1984: Influence of pollution on the taxocenosis of early springs (Plecoptera) of the brook Vydrica (Small Carpathians). - Acta Facultatis Rerum Naturalium Universitatis Comenianae, Zoologia, Bratislava, 27: 41-54.

Krno I., 1986: Stoneflies (Plecoptera) of the Bratislava forest-park (Little Carpathians). - Biológia, Bratislava, 4: 115-125.

Krno I., BulánKová E. \& Halgoš J., 1994: Macrozoobenthos of the Morava river basin and tributaries of the Morava. - Ekológia, Bratislava, 1: 63-76.

LuKÁš J. \& KRno I., 2003: Caddishflies (Trichoptera) of the Gidra river basin. - Acta Zoologica Universitatis Comenianae, Bratislava, 45: 69-75.

Oksanen J., Blanchet F.G., Kindt R., Legendre P., O'Hara R.B., Simpson G.L., Sólymos P., Stevens M.H.H. \& Wagner H., 2010: Community Ecology Package ('vegan'), Ver. 1.17-4 (Aug 2010), http://cran.r-project.org/, http://vegan.r-forge.r-project.org/ (publ. 2010-08-20).

PотосZAK K. \& PoKryszko B.M., 2008: Terrestrial malacocoenoses of the monastery park in Henryków near Ząbkowice Ślaskie (SW. Poland). - Folia Malacologica, 16: 75-87.

StrZelec M. \& Serafiński W., 2004: Biologia i ekologia ślimaków w zbiornikach antropogenicznych [Biology and ecology of snails in athropogenous habitats]. - Centrum Dziedzictwa przyrody Górneho Ślaska, Katowice, 90 pp.

ŠTEFFEK J. \& VAVRovÁ L'., 2006: Current ecosozological status of molluscs (Mollusca) of Slovakia in accordance with categories and criterion of IUCN - version 3.1. (2001). - In: Mollusks: Perspective of Development and Investigation, KYRYCHUK G. YE. (ed.) Conference Proceedings, Zhytomyr, Ukraine 27-29 th September 2006: 266-276.

WhITTAKER R.H., 1972: Evolution and measurement of species diversity. - Taxon, 21: 213-251. 